\title{
Non-destructive genome skimming for aquatic copepods
}

\author{
Vinod Vakati ${ }^{1,2} \cdot$ Steven Dodsworth ${ }^{3}$
}

Received: 3 August 2019 / Accepted: 5 January 2020 / Published online: 21 January 2020

(c) The Author(s) 2020

\begin{abstract}
Copepods are important ecologically and represent a large amount of aquatic biomass in both freshwater and marine systems. Despite this, the taxonomy of copepods and other meiofauna is not well understood, hampered by tiny sizes, cryptic taxa, intraspecific polymorphisms and total specimen destruction where DNA methods are employed. In this article we highlight these issues and propose a more up-to-date approach for dealing with them. Namely, we recommend non-destructive DNA extraction methods, coupled with high-throughput sequencing (HTS). Whilst DNA yields may be low, they should still be sufficient for HTS library preparation and DNA sequencing. At the same time morphological specimens can be preserved and the crucial link between morphology and DNA sequence is maintained. This is critical for an integrative taxonomy and a fuller understanding of biodiversity patterns as well as evolutionary processes in meiofauna.
\end{abstract}

Keywords Non-destructive DNA extraction $\cdot$ Genome skimming $\cdot$ Mitogenomics $\cdot$ Systematics $\cdot$ High-throughput sequencing $\cdot$ DNA barcoding

Subclass Copepoda are often called "insects of the sea", one of the most important and diverse aquatic crustacean groups on the planet in terms of total biomass. They dominate plankton and can be found in aquatic (freshwater to deep-sea) sediments and from ground waters, forest litter, moss, moist soils and wet packed leaves, to Himalayan glacier lakes. Some copepods are free-living and some are associated with a wide range of animals (Walter and Boxshall 2019). The orders Siphonostomatoida and Monstrilloida are exclusively parasites (Fogel et al. 2017; Suárez-Morales 2018), and only some species of the orders Calanoida, Cyclopoida, Canuelloida, and Harpacticoida are parasites or associated with a wide variety of organisms (Boxshall et al. 2016; Ho 2001; Huys 2016). The orders Platycopioida,

Vinod Vakati

vinodbio88@gmail.com

Steven Dodsworth

steven.dodsworth@beds.ac.uk

1 Key Laboratory of Conservation and Utilization of Fish Resources, College of Life Sciences, Neijiang Normal University, Neijiang 641100, China

2 Department of Life Science, College of Natural Sciences, Hanyang University, Seoul 04763, South Korea

3 School of Life Sciences, University of Bedfordshire, University Square, Luton LU1 3JU, UK
Misophrioida, Mormonilloida, and Gelyelloida are completely free-living (Varela and Lalana 2015). Order Calanoida comprises the most diverse and widely distributed group that is the dominant component in zooplankton samples (Huys and Boxshall 1991). Currently, 10,000 valid species of copepods have been recorded and described (Walter and Boxshall 2019), of which 2814 species are reported from freshwaters (Boxshall and Defaye 2008). The approximate number of valid taxa among ten orders is depicted in Fig. 1. It has also been estimated that a large number of species remain undescribed (Humes 1994).

Copepods have tremendous ecological significance and also commercial value: in aquatic food webs and carbon flux (Legendre and Rivkin 2002); control of mosquitoborne diseases by consuming mosquito larvae (Marten et al. 2000); they are prey for higher trophic levels, thus are used in aquaculture (Zeng et al. 2018); considered as a possible food for human consumption (Eysteinsson et al. 2018); as bioindicators of water quality (Annabi-Trabelsi et al. 2019); and a good model to study ecological changes (Grieve et al. 2017). Despite this, copepod species are still a difficult taxonomic group and need to be identified accurately, which is the basic criterion of biodiversity assessment. Cryptic species are frequently encountered from terrestrial to aquatic animals and copepods are no exception (Gomes et al. 2015; Pulido-Santacruz et al. 2018; Ramos 
Fig. 1 An approximate number of total valid taxa in amongst ten orders of Copepoda, subdivided into (i) families and subfamilies; (ii) genera and subgenera, and (iii) species and subspecies. The numbers of taxa are estimated from Walter and Boxshall (2019) and also follow Suárez-Morales (2015)

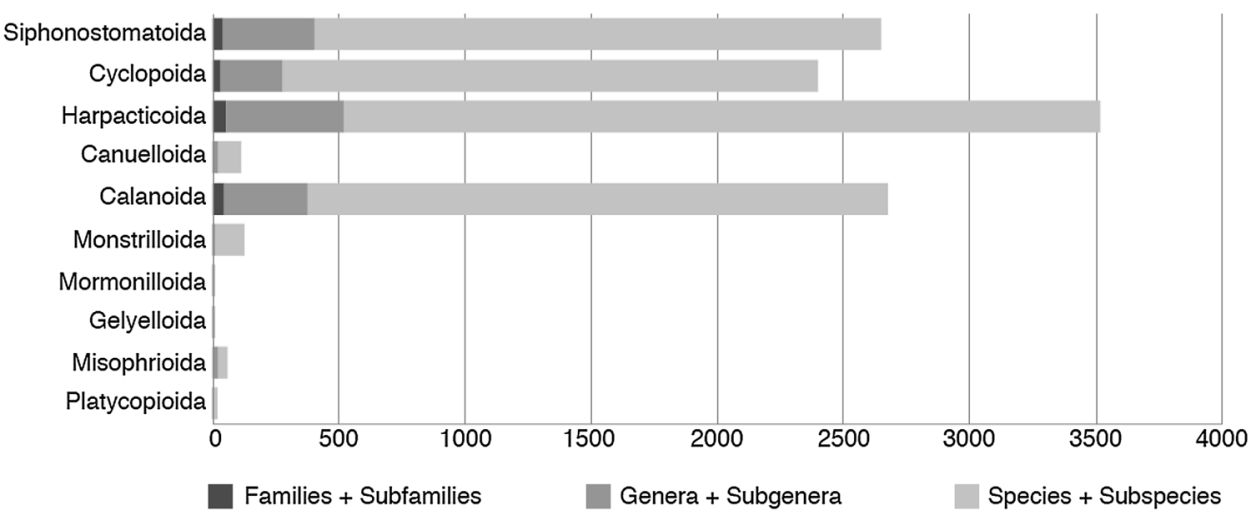

et al. 2019; Vakati et al. 2019). Since such species are genetically divergent while morphologically homogenous, classical taxonomy underestimates their diversity (Lajus et al. 2015; Vakati et al. 2019). Cryptic taxa are often characterised by allopatric distribution patterns (Dodson et al. 2003; Garlitska et al. 2012), however, some cryptic taxa among benthic copepods exist sympatrically (Schizas et al. 2002; Vakati et al. 2019). Although cryptic taxa are morphologically similar, each species may have a different ecological significance, economic value, and interactions with ecosystems (Eisenring et al. 2016), thus, it is crucial to identify these species accurately.

Sometimes the incorrect pairing of sexes can occur among closely related species; for example, $N$. minutus and $N$. dimorphicus are morphologically different but could be misidentified by incorrectly pairing their sexes using classical taxonomy alone (Vakati et al. 2019). Overall, the underestimation of cryptic taxa, plus the inverse problem of variable species being erroneously split are both highly problematic, and especially so if only traditional taxonomic approaches are followed. A more relevant taxonomy is best achieved with an integrative molecular and morphological approach, and newer molecular methods (e.g. non-destructive genome skimming) provide a clear advantage (Fig. 2).

Several works have discussed the importance of integrative taxonomy for meiofauna, with reciprocal illumination based on genetic and morphological identification (CastroRomero et al. 2016; Garraffoni et al. 2019). In the past, specimens have typically been destroyed to extract DNA for molecular analyses and morphological data is thus obtained from different specimens (Di Capua et al. 2017; Karanovic et al. 2015). However, this approach is not effective when several cryptic taxa live sympatrically (Schizas et al. 2002; Vakati et al. 2019). In contrast to macrofauna, meiofauna are extremely small $(50-1000 \mu \mathrm{m})$, so it is difficult to extract genomic DNA (gDNA) from a part of the specimen to obtain genetic and morphological information from the same individual. Recently, non-destructive DNA extraction methods have been suggested as a way to deal with cryptic taxa in copepods (Cornils 2015), whereby specimens are preserved after DNA extraction for morphological studies.

The largest copepod thus far reported grows up to $32 \mathrm{~cm}$, which is Pennella balaenopterae, an ectoparasite of fin whale (Vecchione and Aznar 2014); the smallest copepod thus far reported grows to only to $0.11 \mathrm{~mm}$, males of Sphaeronella monothrix, a parasite of marine ostracods (Bowman and Kornicker 1967). Despite this range of sizes, most copepods are typically small-sized, between 1 and $2 \mathrm{~mm}$ (Walter and Boxshall 2019). A recent study has demonstrated the usefulness of non-destructive DNA extraction, successfully identifying and describing several species of Nannopus from the Yellow Sea (Vakati et al. 2019). In this approach, specimens are first washed in distilled water and subjected to gDNA extraction in lysis buffer, and then subsequently specimens are placed in ethanol for morphological analyses, without damage. Due to their small sizes the concentration of gDNA from a single copepod will be low $(<10 \mathrm{ng} / \mu \mathrm{l})$ and mostly extracted in approximately $20-50 \mu \mathrm{l}$ buffer. Copepods have fragile exoskeletons so care must be taken here. It is not appropriate to extract gDNA from several specimens together to obtain higher concentrations of gDNA, as this heterogeneous mixture of specimens could potentially lead to analytical discrepancies.

Some of the most widely used markers for molecular systematics of copepods are mtCOI, mtCYTB, $18 \mathrm{~S}$ and $28 \mathrm{~S}$ rDNA, and occasionally ITS2, H3, 12S and, 16S rDNA (Braga et al. 1999; Blanco-Bercial et al. 2011; Cornils and Blanco-Bercial 2013; Figueroa 2011; Hirai et al. 2013; Huys et al. 2007; Jørgensen et al. 2010; Khodami et al. 2017; Marrone et al. 2013; Marszalek et al. 2008; Thum 2004; Thum and Harrison 2009; Vakati et al. 2019; von Reumont et al. 2012; Wyngaard et al. 2010). Often universal primers do not effectively amplify both highly variable protein coding genes and conserved ribosomal genes (Cepeda et al. 2012; Lv et al. 2014), and attempting several PCR reactions with ineffective primer combinations can result in wasting gDNA extracts. As an example, we failed to amplify mtCOI even after several attempts using several universal primer combinations 


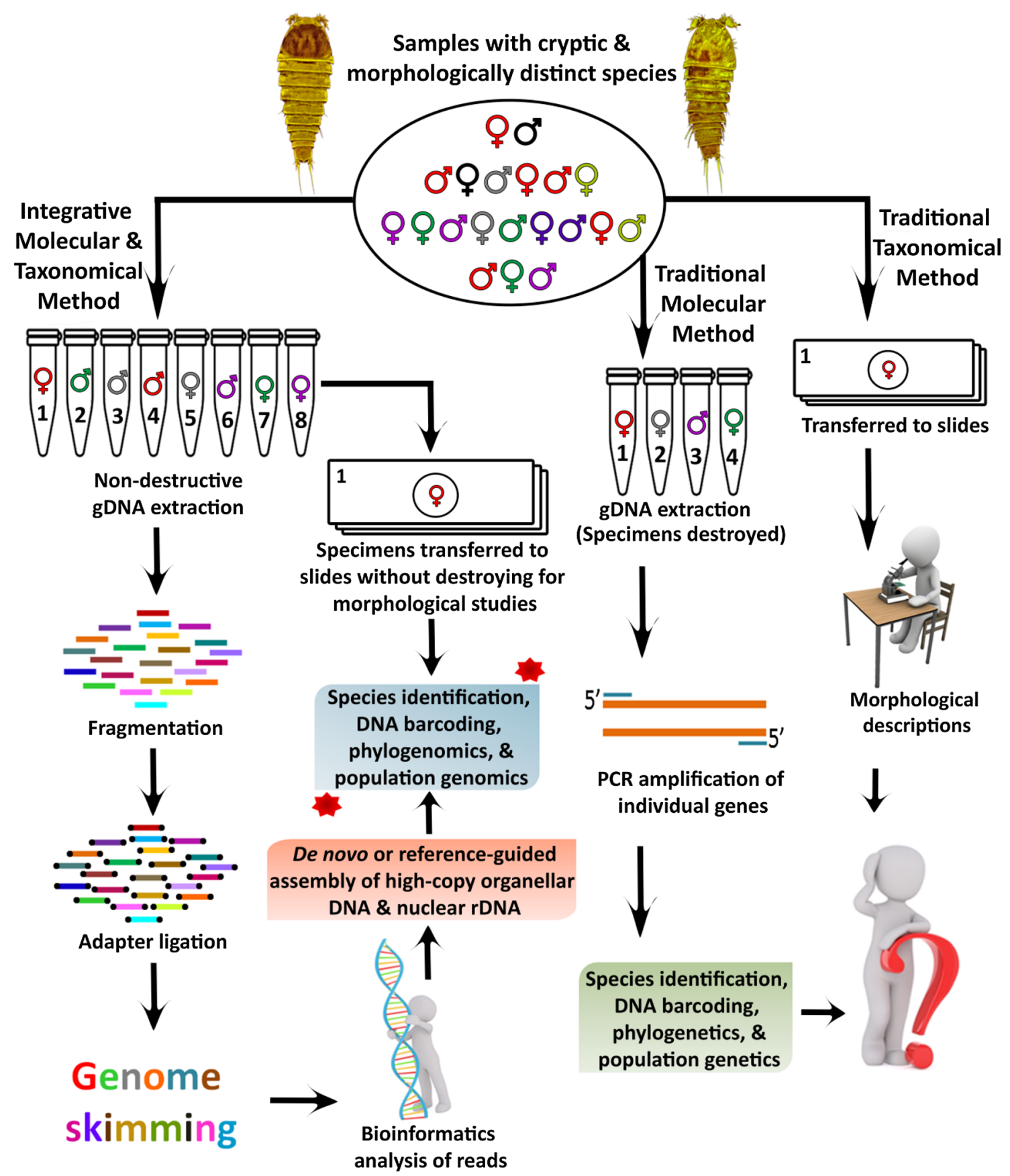

Fig. 2 Summary of gDNA extraction and high-throughput sequencing (HTS) methods applied to evolutionary and ecological studies of meiobenthic animals. Integrative methods involve genetics and morphological observations from the same specimens. Traditional methods demonstrate that results from both morphology-alone or genetics-alone can lead to confusion or discrepancies such as: (i) no guarantee that separate specimens belong to the same species in the case of cryptic taxa; (ii) molecular phylogeny will not have morpho-

for two species of Nannopus, and consequently used all of the gDNA extracts with no additional specimens available (Vakati and Lee in press). An additional problem is that logical data support and vice versa; (iii) classical taxonomy cannot accurately identify cryptic species; (iv) sometimes incorrect pairing of sexes and overestimation of species can happen with classical taxonomy; (v) phylogeny, population genetics, and DNA barcoding based on single genes are often insufficient to resolve relationships; and (vi) single genes often do not amplify effectively with 'universal' primers. Figure adapted from Vakati et al. (2019)

universal primers often amplify pseudogenes (Machida and Lin 2017; Song et al. 2008), which can lead to an overestimation of species and is highly problematic, hindering 
accurate estimates of biodiversity (Song et al. 2008). Highthroughput sequencing (HTS) methods (e.g. genome skimming) are potentially powerful tools to overcome these issues. For example, we employed genome skimming using Illumina technology from approximately $100 \mathrm{ng}$ of DNA $(<5 \mathrm{ng} / \mu \mathrm{l})$, non-destructively extracted from a single specimen of Nannopus ganghwaensis (Vakati et al. 2016), a benthic harpacticoid copepod. The results yielded a complete mitochondrial genome with good coverage (Vakati et al. unpublished).

Genome skimming is a term coined by Straub et al. (2012), and such approaches consist of shallow shotgun sequencing to obtain genomic data from eukaryotic taxa. Scientists have already employed this method in several terrestrial and aquatic animals, as well as plants and protists, for a range of biodiversity research questions (Miller et al. 2011; Richter et al. 2015). However, using such an approach on meiofaunal specimens is currently uncommon, especially for non-model benthic copepods. Although DNA concentrations can be very low, HTS libraries can be prepared routinely from 50 ng of DNA, and theoretically from as little as a few picograms of DNA. Another advantage is that HTS libraries overcome problems associated with less-effective amplification from 'universal' primers, as total DNA is sequenced without the need for specific primer combinations. Genome skimming permits the efficient sequencing of the high-copy portion of nuclear DNA as well as high-copy organellar DNA from a single specimen. This method can therefore be utilized to deal with cryptic taxa even when only one specimen is available.

Phylogenetic relationships of copepod orders have thus far been resolved based only on partial gene sequences (mtCOI, H3, 28S, and 18S rDNA), whereas genome skimming would also help to construct phylogenies based on complete mitogenomes of all orders (and larger stretches of nuclear ribosomal DNA). At the current time, approximately 15 copepod species have complete mitogenomes available and 5 have draft nuclear genome sequences (Jørgensen et al. 2019). Employing genome skimming techniques for meiofauna will also improve genomic databases, which would eventually help further studies in metagenomics and environmental DNA (eDNA) analyses, reducing reliance of such studies on traditional barcode regions. Combining nondestructive DNA extraction with genome skimming, one can identify species and construct phylogenetic relationships more efficiently. This approach has wider implications for species identification, molecular ecology (metabarcoding/ eDNA), DNA barcoding, phylogenomics, and population genetics, and would be a significant step forward for biodiversity research on copepods and meiofauna more broadly.
Acknowledgements We thank the editor and an anonymous reviewer for their valuable comments. We acknowledge the support from the Scientific Research Project of Neijiang Normal University (Grant No. 15ZL04) and the Major Scientific and Technological Achievements Transformation Project of Neijiang Normal University (Grant No. 16CZ04).

\section{Compliance with ethical standards}

Conflict of interest All authors declare that they have no conflict of interest.

Open Access This article is licensed under a Creative Commons Attribution 4.0 International License, which permits use, sharing, adaptation, distribution and reproduction in any medium or format, as long as you give appropriate credit to the original author(s) and the source, provide a link to the Creative Commons licence, and indicate if changes were made. The images or other third party material in this article are included in the article's Creative Commons licence, unless indicated otherwise in a credit line to the material. If material is not included in the article's Creative Commons licence and your intended use is not permitted by statutory regulation or exceeds the permitted use, you will need to obtain permission directly from the copyright holder. To view a copy of this licence, visit http://creativecommons.org/licenses/by/4.0/.

\section{References}

Annabi-Trabelsi N, Shabrawy G, Goher M, Subrahmanyam MNV, AlEnezi Y, Ali M, Ayadi H, Belmonte G (2019) Key drivers for copepod assemblages in a eutrophic coastal brackish lake. Water 11:363. https://doi.org/10.3390/w11020363

Blanco-Bercial L, Bradford-Grieve J, Bucklin A (2011) Molecular phylogeny of the Calanoida (Crustacea: Copepoda). Mol Phylogenet Evol 59:103-113. https://doi.org/10.1016/j.ympev.2011.01.008

Bowman TE, Kornicker LS (1967) Two new crustaceans: the parasitic copepod Sphaeronellopsis monothrix (Choniostomatidae) and its myodocopid ostracod host Parasterope pollex (Cylindroleberidae) from the southern New England coast. Proc US Natl Mus 123:1-28

Boxshall GA, Defaye D (2008) Global diversity of copepods (Crustacea: Copepoda) in freshwater. Hydrobiologia 595:195-207. https ://doi.org/10.1007/s10750-007-9014-4

Boxshall GA, Kihara TC, Huys R (2016) Collecting and processing non-planktonic copepods. J Crustac Biol 36:576-583. https://doi. org/10.1163/1937240x-00002438

Braga E, Zardoya R, Meyer A, Yen J (1999) Mitochondrial and nuclear rRNA based copepod phylogeny with emphasis on the Euchaetidae (Calanoida). Mar Biol 133:79-90. https://doi.org/10.1007/ s002270050445

Castro-romero R, Montes MM, Martorelli SR, Sepulveda D, Tapia S, Martínez-aquino A (2016) Integrative taxonomy of Peniculus, Metapeniculus, and Trifur (Siphonostomatoida: Pennellidae), copepod parasites of marine fishes from Chile: species delimitation analyses using DNA barcoding and morphological evidence. Syst Biodivers 14:466-483. https://doi.org/10.1080/14772 000.2016.1158213

Cepeda GD, Blanco-Bercial L, Bucklin A, Berón CM, Viñas MD (2012) Molecular systematic of three species of Oithona (Copepoda, Cyclopoida) from the Atlantic Ocean: comparative analysis using 28S rDNA. PLoS ONE 7:e35861. https://doi.org/10.1371/ journal.pone.0035861 
Cornils A (2015) Non-destructive DNA extraction for small pelagic copepods to perform integrative taxonomy. J Plankton Res 37:610. https://doi.org/10.1093/plankt/fbu105

Cornils A, Blanco-Bercial L (2013) Phylogeny of the Paracalanidae Giesbrecht, 1888 (Crustacea: Copepoda: Calanoida). Mol Phylogenet Evol 69:861-872. https://doi.org/10.1016/j.ympev .2013 .06 .018

Di Capua I, Maffucci F, Pannone R, Mazzocchi MG, Biffali E, Amato A (2017) Molecular phylogeny of Oncaeidae (Copepoda) using nuclear ribosomal internal transcribed spacer (ITS rDNA). PLoS ONE 12:e175662. https://doi.org/10.1371/journal.pone.0175662

Dodson SI, Grishanin AK, Gross K, Wyngaard GA (2003) Morphological analysis of some cryptic species in the Acanthocyclops vernalis species complex from North America. Hydrobiologia 500:131-143. https://doi.org/10.1023/a:1024678018090

Eisenring M, Altermatt F, Westram AM, Jokela J (2016) Habitat requirements and ecological niche of two cryptic amphipod species at landscape and local scales. Ecosphere 7:e01319. https:// doi.org/10.1002/ecs2.1319

Eysteinsson ST, Gudjónsdóttir M, Jónasdóttir SH, Arason S (2018) Review of the composition and current utilization of Calanus finmarchicus - possibilities for human consumption. Trends Food Sci Technol 79:10-18. https://doi.org/10.1016/j. tifs.2018.06.019

Figueroa DF (2011) Phylogenetic analysis of ridgewayia (Copepoda: Calanoida) from the Galapagos and of a new species from the florida keys with a reevaluation of the phylogeny of Calanoida. $\mathrm{J}$ Crustac Biol 31:153-165. https://doi.org/10.1651/10-3341.1

Fogel D, Fuentes JL, Soto LM, Lafuente W, Moncayo-Estrada R, López C (2017) Ectoparasitic copepod infestation on a wild population of Neotropical catfish Sciades herzbergii Bloch, 1794: histological evidences of lesions on host. Int J Parasitol Parasites Wildl 6:344-348. https://doi.org/10.1016/j.ijppaw.2017.10.001

Garlitska L, Neretina T, Schepetov D, Mugue N, De Troch M, Baguley JG, Azovsky A (2012) Cryptic diversity of the 'cosmopolitan' harpacticoid copepod Nannopus palustris: genetic and morphological evidence. Mol Ecol 21:5336-5347. https://doi.org/10.1111/ mec. 12016

Garraffoni ARS, Araújo TQ, Lourenço AP, Guidi L, Balsamo M (2019) Integrative taxonomy of a new Redudasys species (Gastrotricha: Macrodasyida) sheds light on the invasion of fresh water habitats by macrodasyids. Sci Rep 9:2067. https://doi.org/10.1038/s4159 8-018-38033-0

Gomes LC, Pessali TC, Sales NG, Pompeu PS, Carvalho DC (2015) Integrative taxonomy detects cryptic and overlooked fish species in a neotropical river basin. Genetica 143:581-588. https://doi. org/10.1007/s10709-015-9856-Z

Grieve BD, Hare JA, Saba VS (2017) Projecting the effects of climate change on Calanus finmarchicus distribution within the US Northeast Continental Shelf. Sci Rep 7:6264. https://doi.org/10.1038/ s41598-017-06524-1

Hirai J, Shimode S, Tsuda A (2013) Evaluation of ITS2-28S as a molecular marker for identification of calanoid copepods in the subtropical western North Pacific. J Plankton Res 35:644-656. https://doi.org/10.1093/plankt/fbt016

Ho J-S (2001) Why do symbiotic copepods matter? Hydrobiologia 453:1-7. https://doi.org/10.1023/a:1013139212227

Humes AG (1994) How many copepods? Hydrobiologia 292:1-7. https ://doi.org/10.1007/bf00229916

Huys R (2016) Harpacticoid copepods-their symbiotic associations and biogenic substrata: a review. Zootaxa 4174:448-729. https://doi. org/10.11646/zootaxa.4174.1.28

Huys R, Boxshall GA (1991) Copepod evolution. The Ray Society, London

Huys R, Llewellyn-Hughes J, Conroy-Dalton S, Olson PD, Spinks JN, Johnston DA (2007) Extraordinary host switching in siphonostomatoid copepods and the demise of the Monstrilloida: Integrating molecular data, ontogeny and antennulary morphology. Mol Phylogenet Evol 43:368-378. https://doi.org/10.1016/j. ympev.2007.02.004

Jørgensen A, Faurby S, Hansen JG, Mobjerg N, Kristensen RM (2010) Molecular phylogeny of Arthrotardigrada (Tardigrada). Mol Phylogenet Evol 54:1006-1015. https://doi.org/10.1016/j.ympev .2009 .10 .006

Jørgensen TS, Petersen B, Petersen HCB, Browne PD, Prost S, Stillman JH, Hansen LH, Hansen BW, Milani L (2019) The genome and mRNA transcriptome of the cosmopolitan calanoid copepod acartia tonsa dana improve the understanding of copepod genome size evolution. Genome Biol Evol 11(5):1440-1450

Karanovic T, Kim K, Lee W (2015) Concordance between molecular and morphology-based phylogenies of Korean Enhydrosoma (Copepoda: Harpacticoida: Cletodidae) highlights important synapomorphies and homoplasies in this genus globally. Zootaxa 3990:451-496. https://doi.org/10.11646/zootaxa.3990.4.1

Khodami S, McArthur JV, Blanco-Bercial L, Martinez Arbizu P (2017) Molecular Phylogeny and Revision of Copepod Orders (Crustacea: Copepoda). Sci Rep 7:9164-9164. https://doi.org/10.1038/ s41598-017-06656-4

Lajus D, Sukhikh N, Alekseev V (2015) Cryptic or pseudocryptic: can morphological methods inform copepod taxonomy? An analysis of publications and a case study of the Eurytemora affinis species complex. Ecol Evol 5:2374-2385. https://doi.org/10.1002/ ece 3.1521

Legendre L, Rivkin RB (2002) Fluxes of carbon in the upper ocean: regulation by food-web control nodes. Mar Ecol Prog Ser 242:95109. https://doi.org/10.3354/meps242095

Lv J, Wu S, Zhang Y, Chen Y, Feng C, Yuan X, Jia G, Deng J, Wang C, Wang Q, Mei L, Lin X (2014) Assessment of four DNA fragments (COI, 16S rDNA, ITS2, 12S rDNA) for species identification of the Ixodida (Acari: Ixodida). Parasites Vectors 7:93-93. https:// doi.org/10.1186/1756-3305-7-93

Machida RJ, Lin Y-Y (2017) Occurrence of mitochondrial CO1 pseudogenes in Neocalanus plumchrus (Crustacea: Copepoda): hybridization indicated by recombined nuclear mitochondrial pseudogenes. PLoS ONE 12:e0172710. https://doi.org/10.1371/ journal.pone.0172710

Marrone F, Lo Brutto S, Hundsdoerfer AK, Arculeo M (2013) Overlooked cryptic endemism in copepods: systematics and natural history of the calanoid subgenus Occidodiaptomus Borutzky 1991 (Copepoda, Calanoida, Diaptomidae). Mol Phylogenet Evol 66:190-202. https://doi.org/10.1016/j.ympev.2012.09.016

Marszalek MA, Dayanandan S, Maly EJ (2008) Phylogeny of the genus Hesperodiaptomus (Copepoda) based on nucleotide sequence data of the nuclear ribosomal gene. Hydrobiologia 624:61. https://doi. org/10.1007/s10750-008-9666-8

Marten GG, Nguyen M, Ngo G (2000) Copepod predation on Anopheles quadrimaculatus larvae in rice fields. J Vector Ecol 25:1-6

Miller JM, Malenfant RM, Moore SS, Coltman DW (2011) Short reads, circular genome: skimming SOLiD sequence to construct the bighorn sheep mitochondrial genome. J Hered 103:140-146. https:// doi.org/10.1093/jhered/esr104

Pesce GL (2019) Introduction to copepods. https://www.luciopesce.net/ copepods/intro.htm. Accessed 04 July 2019

Pulido-Santacruz P, Aleixo A, Weir JT (2018) Morphologically cryptic Amazonian bird species pairs exhibit strong postzygotic reproductive isolation. Proc R Soc B 285:20172081. https://doi. org/10.1098/rspb.2017.2081

Ramos EKS, Magalhães RFd, Marques NCS, Baêta D, Garcia PCA, Santos FR (2019) Cryptic diversity in Brazilian endemic monkey frogs (Hylidae, Phyllomedusinae, Pithecopus) revealed by multispecies coalescent and integrative approaches. Mol Phylogenet Evol 132:105-116. https://doi.org/10.1016/j.ympev.2018.11.022 
Richter S, Schwarz F, Hering L, Böggemann M, Bleidorn C (2015) The utility of genome skimming for phylogenomic analyses as demonstrated for glycerid relationships (Annelida, Glyceridae). Genome Biol Evol 7:3443-3462. https://doi.org/10.1093/gbe/evv224

Schizas N, Coull B, Chandler G, Quattro J (2002) Sympatry of distinct mitochondrial DNA lineages in a copepod inhabiting estuarine creeks in the southeastern USA. Mar Biol 140:585-594. https:// doi.org/10.1007/s00227-001-0728-y

Song H, Buhay JE, Whiting MF, Crandall KA (2008) Many species in one: DNA barcoding overestimates the number of species when nuclear mitochondrial pseudogenes are coamplified. Proc Natl Acad Sci USA 105:13486. https://doi.org/10.1073/pnas.08030 76105

Straub SC, Parks M, Weitemier K, Fishbein M, Cronn RC, Liston A (2012) Navigating the tip of the genomic iceberg: Next-generation sequencing for plant systematics. Am J Bot 99:349-364. https:// doi.org/10.3732/ajb.1100335

Suárez-Morales E (2015) Class Maxillopoda. In: Thorp J, Rogers D (eds) Thorp and Covich's freshwater invertebrates, 4th edn. Academic Press, New York, pp 709-755. https://doi.org/10.1016/ B978-0-12-385026-3.00029-2

Suárez-Morales E (2018) Monstrilloid copepods: the best of three worlds. Bull South Calif Acad Sci 117:92-103. https://doi. org/10.3160/3646.1

Thum RA (2004) Using 18S rDNA to resolve diaptomid copepod (Copepoda: Calanoida: Diaptomidae) phylogeny: an example with the North American genera. Hydrobiologia 519:135-141. https:// doi.org/10.1023/B:HYDR.0000026500.27949.e9

Thum RA, Harrison RG (2009) Deep genetic divergences among morphologically similar and parapatric Skistodiaptomus (Copepoda: Calanoida: Diaptomidae) challenge the hypothesis of Pleistocene speciation. Biol J Linn Soc 96:150-165. https://doi.org/10.111 1/j.1095-8312.2008.01105.x

Vakati V, Lee W (2020) On two new species of Nannopus Brady, 1880 (Copepoda: Harpacticoida: Nannopodidae) from intertidal mudflats of the Korean West Coast (Yellow Sea). Zootaxa (in press)
Vakati V, Kihara TC, Lee W (2016) A new species of the genus Nannopus (Copepoda, Harpacticoida, Nannopodidae) from the mudflat of Ganghwa Island, Korea. Proc Biol Soc Wash 129:212-233. https://doi.org/10.2988/0006-324X-129.Q3.212

Vakati V, Eyun SI, Lee W (2019) Unraveling the intricate biodiversity of the benthic harpacticoid genus Nannopus (Copepoda, Harpacticoida, Nannopodidae) in Korean waters. Mol Phylogenet Evol 130:366-379. https://doi.org/10.1016/j.ympev.2018.10.004

Varela C, Lalana R (2015) Copépodos (Crustacea: Maxillopoda; Copepoda) parásitos del archipiélago cubano. Solenodon 12:9-20

Vecchione A, Aznar FJ (2014) The mesoparasitic copepod Pennella balaenopterae and its significance as a visible indicator of health status in dolphins (Delphinidae): a review. J Mar Anim Ecol 7:4

von Reumont BM, Jenner RA, Wills MA, Dell' ampio E, Pass G, Ebersberger I, Meyer B, Koenemann S, Iliffe TM, Stamatakis A, Niehuis O, Meusemann K, Misof B (2012) Pancrustacean phylogeny in the light of new phylogenomic data: support for Remipedia as the possible sister group of Hexapoda. Mol Biol Evol 29:10311045. https://doi.org/10.1093/molbev/msr270

Walter TC, Boxshall G (2019) World of copepods. https://www.marin especies.org/copepoda. Accessed 02 July 2019

Wyngaard GA, Holynska M, Schulte JA 2nd (2010) Phylogeny of the freshwater copepod Mesocyclops (Crustacea: Cyclopidae) based on combined molecular and morphological data, with notes on biogeography. Mol Phylogenet Evol 55:753-764. https://doi. org/10.1016/j.ympev.2010.02.029

Zeng C, Shao L, Ricketts A, Moorhead J (2018) The importance of copepods as live feed for larval rearing of the green mandarin fish Synchiropus splendidus. Aquaculture 491:65-71. https://doi. org/10.1016/j.aquaculture.2018.03.011

Publisher's Note Springer Nature remains neutral with regard to jurisdictional claims in published maps and institutional affiliations. 